\title{
UPAYA PENINGKATAN MOTIVASI BELAJAR SISWA PADA MATA PELAJARAN PENDIDIKAN AGAMA KRISTEN DI KELAS XI SMAN 2 BALIGE BALIGE
}

\author{
Rismauli Berutu \\ Surel: rianasiamanjuntak0712@gmail.com
}

\begin{abstract}
This research was conducted in Class XI SMA Negeri 2 Balige. The goal is to take learning material on the Christian attitude in the development of science. The subject of this research was 28 students in Class XISMA Negeri 2 Balige. This research was conducted with three cycles consisting of four stages, namely planning (plan), action (act), observation (Observe), and reflection (reflex). Student learning outcomes data were captured by pretest and post test. The results of the study concluded that using the jigsaw method can improve student learning motivation. Increasing student learning motivation in the pre-cycle is 50\%,\% (14 students) to $71.4 \%(20$ students) in Cycle II, to $85.71 \%$ (25 students). According to the data above, it can be interpreted that learning motivation has been dominated by some $96.42 \%$ of students. Thus, looking at learning outcomes at the initial observation, there appears to be a significant percentage increase in completeness of student learning outcomes from 50\% (14 students) to 71.4 $\%$ (20 students) in Cycle II, became 85.71\% (25 students), becoming 96.42\% (27 students). Based on the results of the study above the jigsaw method can increase student learning motivation, reduce students' boredom and saturation in learning and make students more active in learning.
\end{abstract}

Keywords: Learning Motivation, Christianity

\begin{abstract}
ABSTRAK
Penelitian ini dilakukan diKelas XI SMA Negeri 2 Balige. Tujuannya dengan mengambil materi pembelajaran Sikap Kristen dalam pengembangan ilmu pengetahuan. Subjek peneliti ini 28 orang siswa diKelas XISMA Negeri 2 Balige. Penelitian ini dilaksanakan dengan tiga siklus yang terdiri dari empat tahapan yaitu perencanaan (plan), tindakan (act), pengamatan (observe), dan refleksi (reflek). Data hasil belajar siswa dijaring dengan pretest dan post test. Hasil penelitian menyimpulkan bahwa dengan menggunakan metode jigsaw dapat meningkatkan motivasi belajar siswa. Peningkatan motivasi belajar siswa pada pra siklus sebesar 50\%,\% (14 orang siswa) menjadi 71,4\% (20 orang siswa) pada Siklus II, menjadi 85,71\% (25 orang siswa). Sesuai data diatas dapat dimaknai bahwa motivasi belajar sudah didominasi oleh sebagian 96,42\% siswa.Dengan demikian, melihat hasil belajar pada observasi awal, nampak adanya peningkatan persentase yang signifikan ketuntasan hasil belajar siswa dari 50\% (14 orang siswa) menjadi $71,4 \%$ (20 orang siswa) pada Siklus II, menjadi $85,71 \%$ (25 orang siswa), menjadi 96,42\% (27 orang siswa). Berdasarkan hasil penelitian diatas metode jigsaw dapat meningkatkan motivasi belajar siswa, mengurangi kebosanan dan kejenuhan siswa dalam belajar dan membuat siswa lebih aktif dalam belajar.
\end{abstract}

Kata Kunci : Motivasi Belajar, Agama Kristen 
Rismauli Berutu: Upaya Peningkatan Motivasi Belajar Siswa...

\section{PENDAHULUAN}

Untuk mencapai tujuan tersebut di atas, maka perlu ditingkatkan motivasi belajar siswa. Siswa yang memiliki semangat dan motivasi belajar yang tinggi serta dapat menerapkan nilai-nilai kristiani tersebut sangat bermanfaat bagi kehidupannya dan kehidupan sesamanya. Misalnya, siswa yang memiliki moral yang baik, dalam lingkungan sekolah maupun di lingkungan masyarakat tahu akan tujuan hidupnya serta dapat merubah tingkah laku sesamanya menuju yang lebih baik. Disamping itu, siswa yang memiliki moral dan kepribadian yang baik akan memberikan dampak yang positif bagi keamanan dan ketertiban Bangsa Indonesia secara umum dan ketentraman hidup dalam bermasyarakat secara khusus.

\section{METODE PENELITIAN}

Tempat penelitian ini dilaksanakan oleh peneliti di Kelas XISMA Negeri 2 Balige.Adapun alasan penulis memilih sekolah ini sebagai tempat penelitian adalah untuk mengembangkan dan menciptakan pembelajaran yang efektif dan efisien dilingkungan sekolah dengan menggunakan metode Cooperative Tipe Jigsaw. Adapun waktu penelitian ini dilaksanakan selama dua bulan. Yaitu bulan Mei sampai bulan Juni 2018, kegiatan peneliti terdiri dari kegiatan izin penelitian, pengumpulan data, analisi data, penyusunan konsep laporan dan diakhiri penyampaian hasil laporan peneliti.

Subjek penelitian ini adalah siswa kelas Kelas XI SMA Negeri 2 Balige., tahun pelajaran 2017/2018 dengan jumlah siswa sebanyak 28 orang. Objek penelitian ini adalah upaya peningkatan motivasi belajar siswa pada mata pelajaran pendidikan agama Kristen melalui metode jigsaw di Kelas XISMA Negeri 2 Balige.

Teknik pengumpulan data merupakan langkah yang paling strategis dalam tindakan penelitian, karena tujuan utama seseorang untuk melakukan penelitian adalah untuk memperoleh data. Tanpa teknik pengumpulan data maka seorang peneliti tidak akan mendapat data yang memenuhi standart yang ditetapkan.

Observasi berfungsi untuk untuk mengumpulkan data atau mengamati siswa dalam belajar.

Observasi ini merupakan pengamatam terhadap seluruh aktifitas dan kegiatan siswa dikelas selama proses pembelajaran berlangsung serta perubahan yang terjadi pada saat dilakukannya tindakan selama proses pembelajaran.

Tes ini dilakukan setelah proses pembelajaran selesai. Hal ini dilakukan untuk mengetahui sejauh mana peningkatan prestasi belajar siswa sebagai akibat dari peningkatan motivasi belajar siswa pada setiap siklus dalam penelitian ini. 
Wawancara juga sangat
penting dilakukan mengumpulkan data kualitatif, karena banyak informasi yang akan peneliti dapatkan dari wawancara tersebut. Wawancara merupakan kegiatan percakapan dengan maksud tertentu, yang dilakukan oleh dua pihak yaitu pewawancara (Peneliti) dan yang diwawancarai (Guru), dengan tujuan agar peneliti dapat menakar pemahaman dalam berlangsungnya proses penelitian. Wawancara ini dilakukan untuk mengetahui sejauh mana keefektifan metode pembelajaran Jigsaw pada mata pelajaran Pendidikan Agama Kristen dalam meningkatkan motivasi belajar siswa.

Refleksi dilakukan setelah selesai pembelajaran dan setelah dilakukannya evaluasi pada siklus pertama (1). Kegiatan ini untuk menganalisis, memprediksikan, menghubungkan, dan menemukan masalah baru yang muncul setelah siklus I, maka akan dilakukannya pengkajian ulang atau penyelesaian masalah pada siklus berikutnya.

Pada tahap perencanaan ini, masalah siklus I dibahas dan penyelesaian masalahnya sehingga hal-hal yang kurang dimengerti menjadi lebih jelas. Selanjutnya mengembangkann program yang akan dilakukan pada siklus II.

Kegiatan belajar dilakukan seoptimal mungkin, didalam kegiatan belajar pada tahap pelaksanaan tindakan ini guru memberikan materi yang akan dibahas, guru harus membentuk kelompok baru, dan menemukan seseorang yang mampu di dalam setiap masing-masing kelompok dan membuat kelompok tim ahli, setelah itu tim ahli akan kembali kemasing-masing kelompok dan bertanggung jawab atas kelompok tersebut dan menjelaskan kembali kepada setiap anggota kelompok. Setelah itu setiap individu akan diberikan test.

Pada tahap ini dilakukan pengamatan kegiatan selama proses pembelajaran berlangsung dengan berpedoman pada lembar observasi. Hal ini untuk dapat mengetahui hasil kegiatan siswa yang telah dilakukan berdasarkan rencana kegiatan yang telah disusun dalam siklus ke II.

Data yang terkumpul berupa hasil observasi dan tes dan wawancara . Data yang diperoleh dianalisis secara deskriptif untuk mengetahui pelaksanaan dan hambatan-hambatan yang terjadi selama pembelajaran. Adapun analisis datanya sebagai berikut: Data observasi dan wawancara dianalisis menggunakan skala penilaian dengan rentang nilai dalam bentuk angka (4, 3, 2, 1) untuk aktivitas siswa yang berarti angka 1 = sangat kurang; $2=$ kurang; $3=$ baik; 4 = sangat baik.

Selanjutnya untuk menganalisis data hasil penelitian yang dikumpulkan dengan memberikan test kepada siswa, dianalisis dengan analisa deskriptif komparatif yaitu dengan membandingkan hasil tes pada siklus awal dengan siklus tindakan penelitian. Data mentah yang 
diperoleh dari hasil tes kemudian diolah melalui cara penyekoran, menilai setiap siswa, menghitung nilai rata-rata kemampuan siswa untuk mengetahui gambaran yang jelas mengenai motivasi belajar dalam memahami pelajaran PAK Nilai yang diperoleh siswa pada saat melaksanakan post-test kemudian dikonversikan terhadap Kriteria Ketuntasan Minimum (KKM) yang dibuat guru untuk menentukan bahwa siswa tersebut mencapai kriteria tuntas atau belum.

Lokasi penelitian pembelajaran adalah di Kelas XI SMA Negeri 2 Balige. . Adapun waktu penelitian pembelajaran ini dilakukan pada semester II tahun ajaran 2017/2018. Mata pelajaran Pendidikan Agama Kristen dengan Metode Jigsaw. Penelitian dilaksanakan dalam tiga siklus, siklus I pada tanggal 11 Mei 2018, siklus II pada tanggal 17 Mei 2018, dan Siklus ketiga pada tanggal 26 Mei 2018 dan sesuai dengan jadwal kegiatan. Penelitian ini di bantu oleh teman sejawat sebagai rekan kerja dan pengamat dalam penelitian ini. Subyek penelitian tindakan kelas ini adalah dengan jumlah siswa 28siswa. Untuk memperoleh gambaran dari hasil penelitian diperlukan data. Data tersebut adalah sejumlah fakta yang digunakan sebagai sumber atau masukan untuk menentukan kesimpulan atau keputusan yang diambil. Yang menjadi topik pengamatan adalah kegiatan siswa, dan hasil pembelajaran siswa pada mata pelajaran Pendidikan Agama Kristen. Berikut data kondisi awal sebelum melaksanakan penelitian.

\section{HASIL PENELITIAN DAN PEMBAHASAN}

Hasil penelitian diuraikan dalam tahapan yang berupa siklussiklus pembelajaran yang dilakukan sebagai berikut: Hasil penelitian siklus I menyajikan laporan hasilhasil setiap tahapan penelitian tindakan kelas, mulai perencanan, pelaksanaan tindakan, observasi dan evaluasi, dan refleksi. Persentase keaktifan siswa yang diperoleh seperti terdapat pada tabel di atas, kemudian dibandingkan dengan kategori penilaian tingkat keaktifan siswa yang telah ditentukan sebelumnya, sebagai berikut Hal itu dapat dilihat dari rata-rata persentase perolehan keaktifan siswa sebesar $57,7 \%$, yaitu berada pada kategori kurang aktif. 
Grafik 1. Perolehan Tingkat Keaktifan Siswa

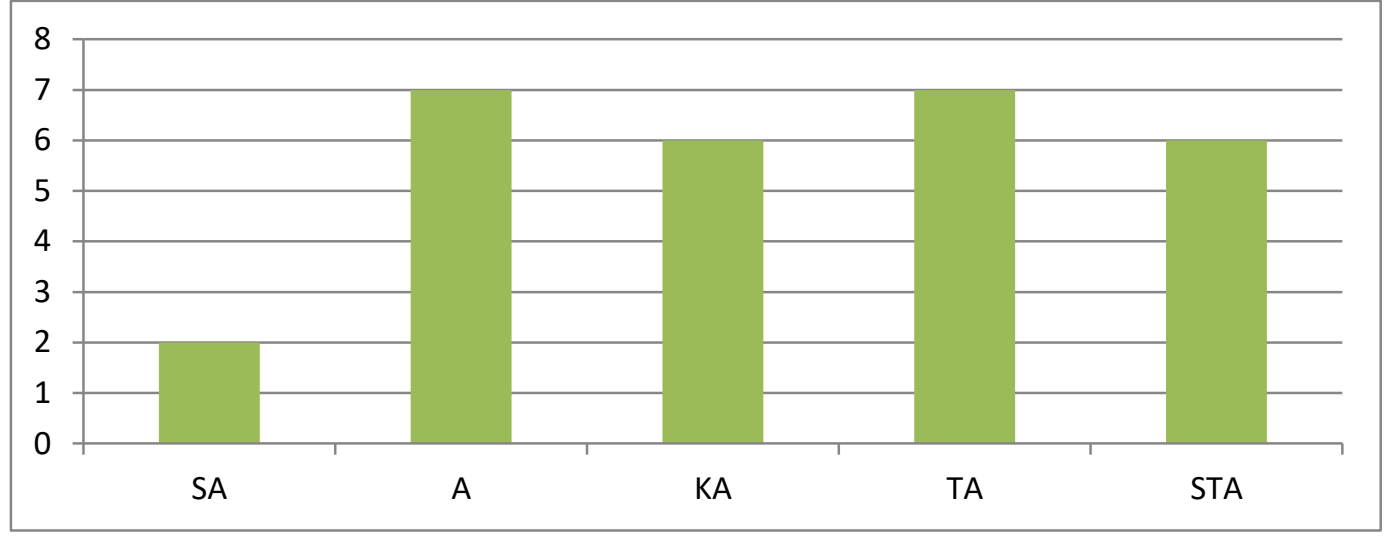

Keterangan:

SA : Sangat Aktif

A : Aktif

KA : Kurang Aktif

TA : Tidak Aktif

STA : Sangat Tidak Aktif

Sesuai data di atas, dapat dimaknai bahwa Motivasi belajar sudah didominasi oleh sebagian besar siswa. Namun demikian, melihat hasil belajar pada observasi awal, nampak adanya peningkatan persentase ketuntasan hasil belajar siswa dari $50 \%$ (14 orang siswa) menjadi $71,4 \%$ (20 orang siswa). Hasil penelitian siklus I menyajikan laporan hasil-hasil setiap tahapan penelitian tindakan kelas, mulai perencanan, pelaksanaan tindakan, observasi dan evaluasi, dan refleksi. Setelah mempertimbangkan hasil refleksi pada siklus pertama, maka pada siklus kedua peneliti mencoba menyempurnakan pelaksanaan perbaikan pembelajaran.

Berdasarkan hasil tindakan I, faktor yang diduga menjadi penyebab timbulnya permasalahan tersebut adalah metode yang dipakai kurang bisa membantu siswa untuk menuangkan idenya karena siswa baru mengenal metode pembelajaran Jigsaw. Pada waktu guru mengajar, peneliti dibantu teman sejawat untuk melakukan pengumpulan data dengan cara mencatat kejadiankejadian selama kegiatan pembelajaran berlangsung untuk mengetahui sejauh mana Motivasi belajar siswa sebelum dan sesudah diberi tindakan. Untuk mengetahui perkembangan prestasi belajar siswa dilakukan melalui tes yang diberikan diakhir siklus. Kegiatan pengamatan siklus II, dilakukan untuk mengetahui peningkatan motivasi belajar siswa siswa dalam proses belajar mengajar berlangsung dengan menggunakan metode Jigsaw. Untuk memudahkan peneliti dalam mengumpulkan data tentang peningkatan motivasi belajar siswa, maka peneliti membuat tabel pedoman penilaian peningkatan motivasi belajar siswa, seperti berikut:

Persentase $=\frac{\text { SkorPerolehanx } 100 \%}{\text { SkorMaksimal }}$ 
Rismauli Berutu: Upaya Peningkatan Motivasi Belajar Siswa...

Kategori Penilaian Tingkat Keaktifan

$90 \%-100 \% \quad$ Sangat Tinggi

$75 \%-89 \% \quad$ Tinggi

$55 \%-74 \% \quad$ Normal

$35 \%-54 \% \quad$ Rendah

$0 \%-34 \% \quad$ Sangat Rendah
Kegiatan pengamatan siklus II ini dilakukan untuk mengetahui lebih lanjut bagaimana peningkatan motivasi belajar siswa selama proses belajar mengajar berlangsung dengan menggunakan metode Jigsaw.

Grafik 2. Perolehan Tingkat Keaktifan Siswa

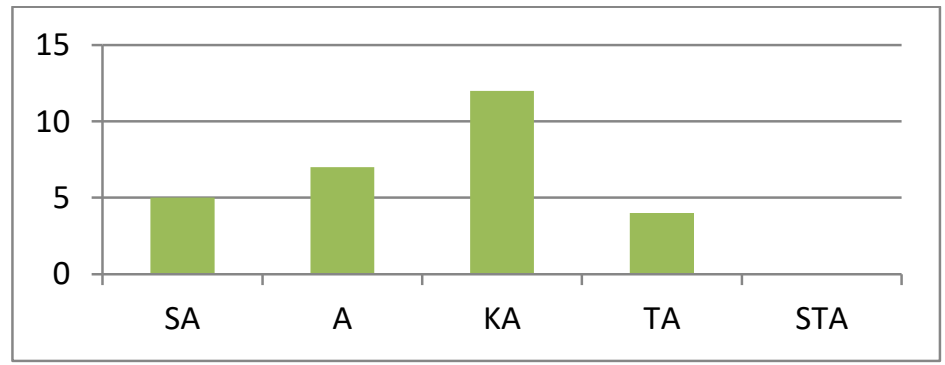

Siklus III ini merupakan upaya perbaikan dari siklus sebelumnya. Jadi sebagaimana pada perencanaan siklus I dan II, perencanaan dalam siklus ini dituangkan dalam bentuk Silabus dan Rencana Pelaksanaan Pembelajaran (RPP) yang dibuat dengan merujuk kepada Metode Jigsaw. Menetapkan Sumber belajar merujuk pada hasil pengamatan siswa di lapangan dan buku paket mata pelajaran serta. Menyiapkan format wawancara yang akan digunakan peneliti untuk mengetahui keefektifan penggunaan metode jigsaw dalam meningkatkan motivasi belajar siswa. Pertanyaan-pertanyaan wawancara tersebut akan diajukan kepada kolaborator yang bertindak sebagai pengamat, baik sebagai pengamat keaktifan belajar siswa maupun sebagai pengamat penerapan metode Jigsaw pada mata pelajaran Pendidikan Agama Kristen.

Berdasarkan hasil yang dicapai pada tindakan kelas siklus II maka rencana tindakan kelas siklus II perlu direvisi yang hasilnya akan digunakan sebagai acuan pelaksanaan tindakan kelas siklus III. Beberapa revisi yang disepakati dengan guru kelas yaitu:

a. Prosedur pembelajaran diupayakan lebih menarik lagi agar aktifitas dan efikasi diri siswa semakin meningkat.

b. Guru lebih mengoptimalkan pemberian motivasi untuk meningkatkan aktivitas belajar siswa.

c. Proses pembelajaran harus berpusat pada siswa.

d. Guru berusaha mendorong semua siswa agar berpartisipasi secara aktif dalam menjawab pertanyaan pada saat pembelajaran berlangsung.

\section{Pembahasan}

Pelaksanaan pada tindakan III ini sama dengan tindakan I dan II. Namun pada pelaksanaan tindakan 
III ini peneliti menggunakan strategi tanya jawab dengan jumlah kelompok yang lebih kecil agar mereka bisa mengungkapkan pendapatnya dengan lebih baik.

Dengan melihat dari pelaksanaan tindakan I dan II maka dalam tindakan III ini, diharapkan bisa memberi peningkatan yang signifikan terhadap efikasi diri siswa dalam proses belajarnya. Peneliti dan guru melakukan pengamatan terhadap penerapan Metode Jigsaw dalam meningkatkan pemahaman siswa yang tujuannya adalah efikasi diri, Peneliti juga mengamati perubahan yang terjadi pada tindakan III dapat dimaknai bahwa Motivasi belajar sudah didominasi oleh sebagian 96,42\% siswa. Dengan demikian, melihat hasil belajar pada observasi awal, nampak adanya peningkatan persentase yang signifikan ketuntasan hasil belajar siswa dari $50 \%$ (14 orang siswa) menjadi $71,4 \%$ (20 orang siswa) pada Siklus II, menjadi $85,71 \%$ (25 orang siswa), menjadi $96,42 \%$ (27 orang siswa).

Dari jawaban tersebut di atas dapat disimpulkan bahwa metode pembelajaran tipe Jigsaw sangat baik digunakan untuk merangsang siswa selama proses pembelajaran Pendidikan Agama Kristen berlangsung. Dalam metode Jigsaw ini, siswa lebih aktif dalam mengikuti pelajaran sebagaimana terlihat dari peningkatan motivasi belajar siswa yang terdapat pada hasil observasi setiap siklus.

\section{SIMPULAN}

Berdasarkan analisis data dan hasil penelitian tindakan kelas (Classroom Action Research) yang dilakukan dapat disimpulkan bahwa: 1) Penggunaan pembelajaran metode jigsaw dapat meningkatkan motivasi belajar siswa Kelas XI SMA Negeri 2 Balige. Hasil observasi keaktifan belajar siswa dari siklus I hingga siklus III menunjukkan terjadinya peningkatan motifasi belajar pada mata pelajaran Pendidikan Agama Kristen. Dari siklus I ke siklus II terjadi peningkatan sebesar 12,8\%, dimana rata-rata keaktifan belajar siswa pada siklus I dan siklus II masing-masing adalah $57,7 \%$ dan 70,5\%. Dari siklus II ke siklus III terjadi peningkatan sebesar 5,9\%, dimana rata-rata keaktifan belajar siswa pada siklus III adalah $76,4 \%$. 2) Hasil peningkatan motivasi belajar siswa juga dibuktikan dengan melihat membandingkan hasil belajar siswa pada setiap siklus. Melihat hasil belajar pada observasi awal, nampak adanya peningkatan persentase ketuntasan hasil belajar siswa dari $50 \%$ (14 orang siswa) menjadi $71,4 \%$ (20 orang siswa) pada Siklus II, menjadi 85,71\% (25 orang siswa). Sesuai data diatas dapat dimaknai bahwa motivasi belajar sudah didominasi oleh sebagian 96,42\% siswa. Dengan demikian, melihat hasil belajar pada observasi awal, nampak adanya peningkatan persentase yang signifikan ketuntasan hasil belajar siswa dari $50 \%$ (14 orang siswa) menjadi $71,4 \%$ (20 orang siswa) 
Rismauli Berutu: Upaya Peningkatan Motivasi Belajar Siswa...

pada Siklus II, menjadi $85,71 \%$ (25

orang siswa), menjadi $96,42 \%$ (27

orang siswa), 3) Metode

Pembelajaran Jigsaw dapat

meningkatkan Motivasi belajar

siswa. Data hasil observasi

memperlihatkan bahwa terjadi

peningkatan motivasi belajar siswa.

\section{DAFTAR RUJUKAN}

Boehlke, Robert. R. 2007. Sejarah

Perkembangan Pemikiran dan

Praktek PAK dari Plato

sampai Lg. Loyola, cetakan 3.

Jakarta: Bpk Gunung Mulia.

Cully, Iris.V. 1989. Dinamika

Pendidikan Agama Kristen.

Jakarta: BPK Gunung Mulia.

Dimyati dan Mudjiono. 2009.

Belajar dan Pembelajaran.

Jakarta: Rineka Cipta.

Gultom, Ramli. 2010. Menjadi Penulis Penelitian Tindakan di kelas dan di sekolah. Balige:

USU Perss.

Harefa, Etiknius. 2013. Diktat Metodologi Penelitian

Tindakan Kelas, Balige. 
Rismauli Berutu: Upaya Peningkatan Motivasi Belajar Siswa... 